\title{
Soil seed bank and floristic diversity in a forest-grassland mosaic in southern Spain
}

\author{
Díaz-Villa, M.D. ${ }^{1}$; Marañón, T. . ${ }^{*}$; Arroyo, J.2 \& Garrido, B. ${ }^{2}$ \\ ${ }^{1}$ IRNA, CSIC, P.O. Box 1052, E-41080 Sevilla, Spain; ${ }^{2}$ Departamento de Biología Vegetal y Ecología, Universidad de \\ Sevilla, Apartado 1095, E-41080 Sevilla, Spain; *Corresponding author; E-mail teodoro@irnase.csic.es
}

\begin{abstract}
Soil seed bank and floristic diversity were studied in a forest of Quercus suber, a forest of Quercus canariensis and a grassland, forming a vegetation mosaic in Los Alcornocales Natural Park, southern Spain. The soil seed bank was estimated by the germination technique. In each community patch, diversity, woody species cover and herbaceous species frequency was measured. Three biodiversity components - species richness, endemism and taxonomic singularity - were considered in the vegetation and the seed bank. Forest patches had a soil seed bank of ca. 11 200-14 100 seed. $\mathrm{m}^{-2}$ and their composition had low resemblance to (epigeal) vegetation. The grassland patch had a more dense seed bank (ca. 31800 seed. $\mathrm{m}^{-2}$ ) and a higher index of similarity with vegetation, compared with the forests nearby. The complete forest diversity was $71-78$ species on 0.1 ha, including $12-15$ species found only in the seed bank; the grassland species richness was higher (113 species on 0.1 ha). We discuss the role of soil seed banks in the vegetation dynamics and in the complete plant biodiversity of the mosaic landscape studied.
\end{abstract}

Keywords: Biodiversity; Forests conservation; Mediterranean forest; Regeneration; Species richness.

Nomenclature: Valdés et al. (1987).

\section{Introduction}

Forest soils under a mediterranean type climate usually contain a substantial reserve of viable seeds, although the composition and relative abundance of this seed bank has a low resemblance to the (epigeal) vegetation (Trabaud 2000; Marañón 2001).

The existence of soil seed banks in forests has several ecological consequences:

1. At the population level, the lasting seed reserve in the soil may reduce the local extinction risk of vulnerable species (Venable \& Brown 1988; Aparicio \& Guisande 1997).

2. The seed bank is a reflection of past environmental conditions and tends to have a different genetic structure to that of above-ground plants, thus possibly affecting evolutionary trends (Levin 1990; Aparicio et al. 2002). 3 . At the community level, the reservoir of propagules in the forest soil regenerates the vegetation after disturbances (Hyatt \& Casper 2000).

4. Species with a seed bank may co-exist in temporally variable environments (Pake \& Venable 1995), contributing to the community diversity. In fact, the floristic diversity of a vegetation patch should include the species contained in its soil seed bank (Major \& Pyott 1966).

Most of the studies of soil seed banks in Mediterranean forests and shrublands have been focused on the regeneration after fire: e.g. Valbuena \& Trabaud 1995; Ferrandis et al. 1996, 1999; Trabaud et al. 1997; Calvo et al. 1999. There are fewer studies dealing with soil seed banks and biodiversity of little disturbed Mediterranean forests.

A forest is a mosaic of patches with different regeneration stages (Spies \& Turner 1999). Some species can be found as buried seeds in the soil, persisting after past disturbances until new gaps are opened. The forest biodiversity should include this species richness hidden in the soil seed bank. In general, studies dealing with vegetation diversity in mediterranean type climates are restricted to the epigeal plant diversity, and ignore seed banks stored in the soil - a part of the plant diversity whose recording requires more time and effort. Reviews of diversity studies at the 0.1 -ha scale have been carried out by Westman (1988) and Ojeda et al. (2000).

In this paper, we study (1) the soil seed bank of three patches in a vegetation mosaic: evergreen Quercus suber forest, semi-deciduous $Q$. canariensis forest and open grassland, located in a protected Natural Park and relatively undisturbed; (2) the relationship in composition and abundance between the soil seed bank and the vegetation; (3) the biodiversity of each community patch, including the species richness buried in the soil as seeds; (4) the landscape mosaic diversity and the floristic similarity between patches, discussing the potential flow of propagules between them. 


\section{Material and Methods}

\section{Study area}

The study plots were located in the upper part of the Hozgarganta Basin, in the north of Los Alcornocales Natural Park (southern Spain, see Fig. 1). This Park covers ca. $1700 \mathrm{~km}^{2}$ of rough relief, the highest point being a peak of $1092 \mathrm{~m}$. Oligo-Miocene sandstone rocks are dominant in these mountains, originating sandy, acidic soils, although interspersed with clay deposits and clayey soils. The climate is mediterranean, with mild, humid winters and warm, dry summers. The annual precipitation ranges from $665 \mathrm{~mm}$ to $1210 \mathrm{~mm}$, associated to orographic variability; the annual mean temperature is $16-18^{\circ} \mathrm{C}$, with a maximum of $31^{\circ} \mathrm{C}$ and minimum of $5{ }^{\circ} \mathrm{C}$.

The vegetation is a mosaic of forests dominated by Quercus suber (evergreen) and Q. canariensis (semideciduous) on sandy, acidic soils, mixed with grassland patches on clayey soils (Fig. 1). Other vegetation types in the Natural Park are the open heathlands on ridge tops, the wild Olea europaea on lowlands with clayey soil, and the riparian forests (see description in Ojeda et al. 2000). The forest is managed mainly for cork extraction (from $Q$. suber bark), for browsing by free-range livestock and game animals and - more recently - for eco-tourism (Anon. 1997a).

\section{Sampling of vegetation and seed bank}

One representative patch of each main vegetation type $-Q$. suber forest, $Q$. canariensis forest and grassland - was selected. In each patch, a permanent plot of $20 \mathrm{~m} \times 50 \mathrm{~m}(0.1 \mathrm{ha})$ was marked out. Linear cover of tree and shrub layers was measured along two 50-m lines within the plot. Herbaceous species were recorded in 20 quadrats $\left(0.25 \mathrm{~m}^{2}\right)$, regularly distributed (every 5 $\mathrm{m}$ ) on each of the 50-m lines; sampling of herbaceous species was repeated five times (March, June and Octo-
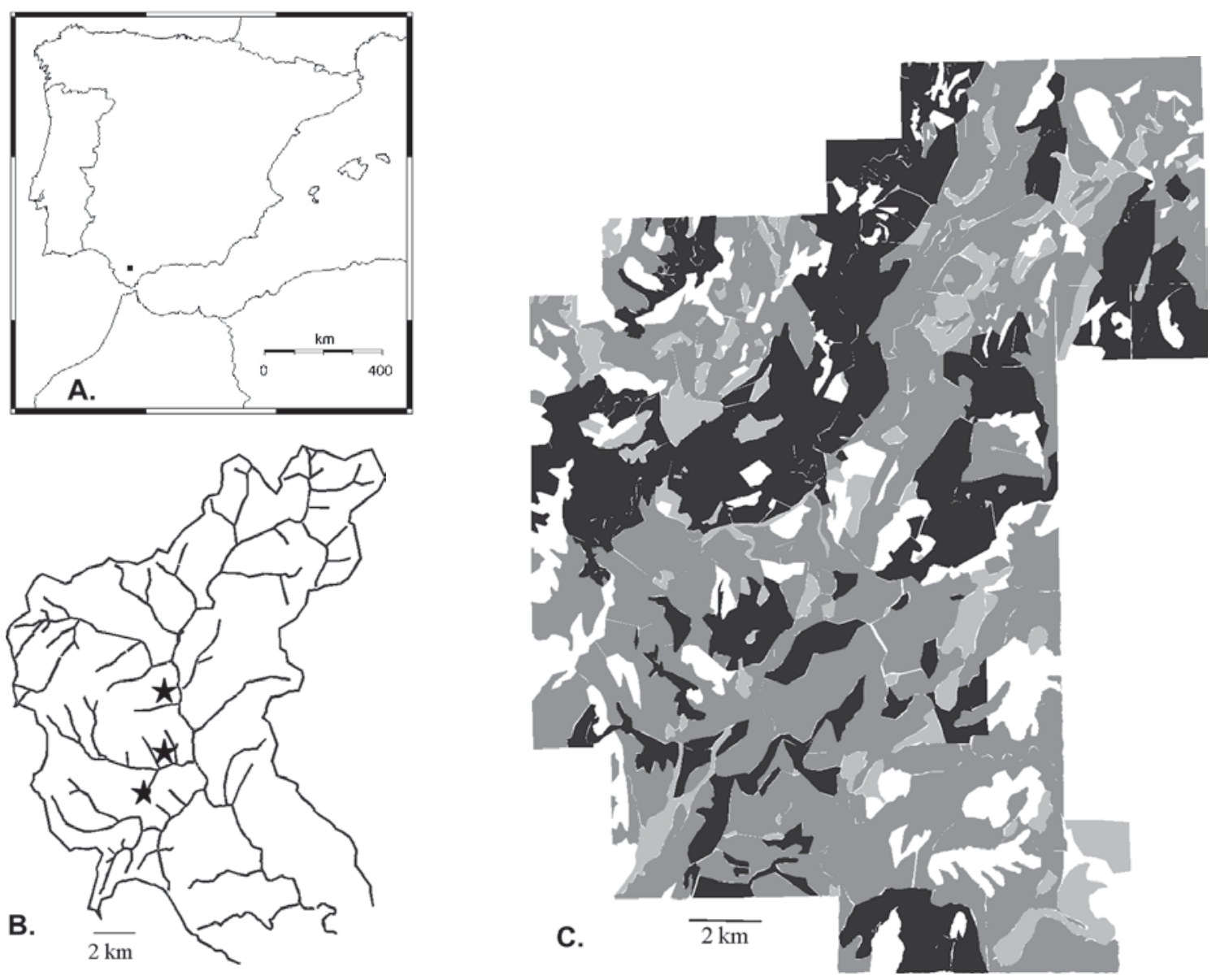

Fig. 1. A. Location of the study area (black rectangle) in the South of the Iberian Peninsula. B. Map of the upper Hozgarganta Catchment Basin and location of the study sites (stars). C. Local vegetation mosaic formed by Quercus canariensis forest (black), Q. suber forest (dark grey) and grassland (light grey). Other types (Olea europaea forest, shrublands, heathlands and forest plantations) are shown in white. (Modified after Anon. 1990.) 
ber 1997, March and April 1998) to cover phenological variation and to record maximum diversity.

Ten soil cores $(8 \mathrm{~cm}$ diameter $\times 4 \mathrm{~cm}$ depth) were taken in each patch during autumn 1998. Soil samples were transported to a glasshouse and spread over a sterile sand bed in trays, forming a thin layer ca. $3 \mathrm{~mm}$ deep. They were kept moist for nine months, left to dry and kept in the dark during the summer, then again exposed to light and watered for seven more months. Emergent seedlings were identified, counted and discarded. When necessary, they were transplanted to pots until growth and flowering allowed their identification. A small percentage of seedlings $(1.4 \%$ in $Q$. suber forest, $7.6 \%$ in $Q$. canariensis forest and $4.6 \%$ in grassland) could not be identified; they were, however, included in the species richness calculation as different plant-morphs.

\section{Biodiversity analysis}

Biodiversity was analysed at two spatial scales: at the 0.1-ha scale to compare our results with the existing data base on Mediterranean vegetation (Westman 1988; Ojeda et al. 2000) and at the $0.25-\mathrm{m}^{2}$ scale to examine the pattern of herbaceous vegetation and the relationship with the seed bank.

Biodiversity has been defined as a multicomponent parameter at the community level, summarising the information content of the species (see Ojeda et al. 1995 for details). For each patch (0.1-ha plot), we have calculated the species richness, the endemic taxa richness and the taxonomic singularity, following the methodology described in Ojeda et al. (1995). Species richness is the total number of species in the plot. Endemic richness has been calculated as the number of taxa (species or subspecies) with Ibero-North-African or smaller area distribution. Taxonomic singularity has been calculated as the inverse of the mean of infrageneric diversity (at the scale of the western Andalusian flora) for all the species in the community (Ojeda et al. 1995).

We have defined 'site diversity' as the cumulative species richness of a site, including the vegetation and the soil seed bank. The complete list of plant species in a particular site, both epi- and hypogeal, is frequently a heterogeneous mixture of plants, characteristic of different habitats, a reflection of past historical disturbances and, at the same time, a reservoir for future changes.

\section{Data analyses}

Seed bank density and species richness, as well as biodiversity components of both sections - seed bank and vegetation, were compared between the three community patches by means of ANOVA and multiple comparison test (Tukey). When data distributions did not satisfy assumptions of normality and homocedasticity, even after logarithmic transformation, non-parametric tests (Kruskal-Wallis and Mann-Whitney $U$ ) were applied. This comparison between patches is exploratory and the results are preliminary for the community types.

The similarity between the species composition of the seed bank and that of the vegetation was calculated by the Sørensen index (Mueller-Dombois \& Ellenberg 1974). For the herbaceous layer, we compared the composition of soil seed bank (ten samples) with the composition of adjacent $0.25-\mathrm{m}^{2}$ quadrats (ten quadrats). For the tree and shrub layer, we compared the composition of the seed bank with the woody species list at the 0.1-ha scale. The relationship between species composition in the vegetation patches and in the soil seed bank was further explored by means of Detrended Correspondence Analysis (DCA: McCune \& Mefford 1999). Statistical analyses were performed using STATISTICA (Anon. 1997b).

\section{Results}

\section{Seed bank diversity and density}

The forest soil examined presented a seed bank of high density and diversity: mean of 14125 seed.m ${ }^{-2}$ belonging to 32 species in the $Q$. canariensis forest and 11240 seed. $\mathrm{m}^{-2}$ of 27 species in the $Q$. suber forest (Table 1). Seeds of woody plants were very abundant in the soil bank of $Q$. suber forest (56.3\% of total seeds) and less in the $Q$. canariensis forest (27.5\%); only four of the 25 woody species recorded in the forest patches were found in the seed bank. Dominant species in the seed banks of these forests were Erica arborea and $E$. scoparia; also remarkable was the high number of spores of Asplenium onopteris (see App. 1).

The soil seed bank in the grassland had a significantly higher density and diversity than in nearby forests (see ANOVA results in Table 1). A mean of 31811 seed. $\mathrm{m}^{-2}$ belonging to 51 species, with a majority of annuals (71.8\% of the seed bank), was found in these grassland soils. Dominant species in the seed bank of the grassland were Mentha pulegium, Agrostis pourretii and Cerastium glomeratum (App. 1). 
Table 1. Diversity and density of the soil seed bank (mean and s.d., $n=10$ ), total species richness (cumulative for ten samples) and proportion of seeds belonging to different life forms in the three communities studied. ANOVA results $(F$ and $p)$ are indicated; different superscript letters in the same row mean significant differences $(p<0.05)$ after a Tukey test.

\begin{tabular}{|c|c|c|c|c|c|c|}
\hline & & \multirow[t]{2}{*}{ Quercus suber forest } & \multirow[t]{2}{*}{ Quercus canariensis forest } & \multirow[t]{2}{*}{ Grassland } & \multicolumn{2}{|c|}{ ANOVA } \\
\hline & & & & & $F$ & $p$ \\
\hline Seed density & Mean (seeds m ${ }^{-2}$ ) $(\mathrm{SD})$ & $11240^{\text {a }}(5749)$ & $14125^{\mathrm{a}}(8310)$ & $31811^{\mathrm{b}}(12185)$ & 14.85 & $<0.001$ \\
\hline Bank diversity & Mean(no. spp./sample) (SD) & $9.4^{\text {a }}(2.3)$ & $9.1^{\mathrm{a}}(2.9)$ & $19.1^{\mathrm{b}}(5.4)$ & 22.62 & $<0.001$ \\
\hline \multirow{2}{*}{\multicolumn{2}{|c|}{$\begin{array}{l}\text { Total species richness } \\
\text { Proportion of life forms }(\%)\end{array}$}} & 27 & 32 & 51 & & \\
\hline & & & & & & \\
\hline \multirow{2}{*}{\multicolumn{2}{|c|}{$\begin{array}{l}\text { woody } \\
\text { perennial herbs }\end{array}$}} & 56.3 & 27.5 & 0.0 & & \\
\hline & & 24.4 & 42.8 & 28.2 & & \\
\hline \multicolumn{2}{|l|}{ annual herbs } & 19.3 & 29.7 & 71.8 & & \\
\hline
\end{tabular}

\section{Relationship between seed bank and vegetation}

In general, the similarity between the species composition of seed bank and vegetation was relatively low (App. 1 and 2). Only a fraction of the (epigeal) vegetation species richness was found in the soil seed bank: $22.7 \%$ of species in the $Q$. suber forest, $30.4 \%$ in the $Q$. canariensis forest and $33.3 \%$ in the grassland (data for the 0.1 -ha scale).

More important was the presence of a significant number of species as viable seeds buried in the soil, but not found as adult plants in the vegetation: 12 in the $Q$. suber forest, 15 in the Q. canariensis forest and 20 in the grassland (data for the 0.1-ha scale). This added forest biodiversity ( 31 species in total) was composed of herbaceous species of different families: 8 Fabaceae, 5 Poaceae, 3 Asteraceae and 3 Juncaceae, among others (App. 1).

The similarity between soil seed bank and vegetation, for the herbaceous layer, varied from 36-39\% in forest patches to $45 \%$ in the grassland (Table 2). Herbaceous perennials, as a life form, had the highest values of similarity index between seed bank and vegetation, in particular in the grassland patch.

DCA analysis was performed on a total of 147 species and 60 samples ( 30 soil seed bank and 30 nearby quadrat inventories) (graph not shown). Forest samples (both seed bank and quadrats) were distributed at the positive extreme of the first axis (eigenvalue $=0.879$ ), clearly separated from grassland samples, which were associated to heliophilous species such as Rumex bucephalophorus, Stegia trimestris, Tetragonolobus purpureus and Molineriella minuta. The second axis (eigenvalue $=0.661$ ) ordered forest understorey samples along a moisture gradient. At the positive extreme were herbaceous species from more moist $Q$.canariensis forest such as Luzula forsteri, Arisarum proboscideum and Aristolochia paucinervis, while the opposite extreme gathered the species associated to drier $Q$. suber forest such as Rubia agostinhoi, Teucrium scorodonia and Bellis sylvestris.

A second DCA analysis of 67 species and 40 samples was carried out only for the forest patches (Fig. 2). The first axis (eigenvalue $=0.722$ ) distinguished the samples from the two forest types. The second axis (eigenvalue $=$ 0.534 ) separated, in each forest, the soil seed bank samples from the vegetation. Characteristic species of the soil seed bank (lowest scores for axis 2) were Trifolium glomeratum, Carexflacca, Anagallis arvensis and Agrostis stolonifera in the Q. suber forest; Stellaria media, Agrostis tenerrima and Asplenium onopteris (spore bank) in the $Q$. canariensis forest and Juncus bufonius in both forest patches (Fig. 2 and App. 1).

Table 2. Comparison of species composition between soil seed bank and herbaceous vegetation. Number of species recorded in the seed bank (Bank), vegetation (Veg), and in both sections (Com) are indicated. Sørensen similarity indexes (SI) have been calculated at the $0.25-\mathrm{m}^{2}$ scale.

\begin{tabular}{|c|c|c|c|c|c|c|c|c|c|c|c|c|}
\hline \multirow[b]{2}{*}{ Life form } & \multicolumn{4}{|c|}{ Quercus suber forest } & \multicolumn{5}{|c|}{ Quercus canariensis forest } & \multicolumn{3}{|c|}{ Grassland } \\
\hline & Bank & Veg & Com & SI $(\%)$ & Bank & Veg & Com & SI $(\%)$ & Bank & Veg & Com & $\mathrm{SI}(\%)$ \\
\hline - Annuals & 13 & 5 & 2 & 22 & 12 & 1 & 0 & 0 & 41 & 49 & 18 & 40 \\
\hline - Perennials & 11 & 16 & 6 & 44 & 17 & 21 & 10 & 53 & 10 & 19 & 9 & 62 \\
\hline Total & 24 & 21 & 8 & 36 & 29 & 22 & 10 & 39 & 51 & 68 & 27 & 45 \\
\hline
\end{tabular}


Table 3. Species richness, endemism and taxonomic singularity (mean \pm s.d.) for the herbaceous vegetation $\left(20\right.$ samples of $\left.0.25 \mathrm{~m}^{2}\right)$ layer, and for the soil seed bank (ten soil cores) in the three plant communities studied. Only herbaceous species were considered in the soil seed bank calculations. Values of $F$ for ANOVA analysis and of non-parametric $H$ for the Kruskal-Wallis tests are indicated $(* *=p<0.01 ; * * *=p<0.001)$. Same letters in a row indicate non-significant differences between community patches after performing a Tukey test or non-parametric Mann-Whitney U-test.

\begin{tabular}{|c|c|c|c|c|}
\hline & Quercus suber forest & Quercus canariensis forest & Grassland & Statistical test \\
\hline \multicolumn{5}{|l|}{ Vegetation } \\
\hline - Species richness & $6.2 \pm 2.1^{\mathrm{a}}$ & $5.8 \pm 2.4^{\mathrm{a}}$ & $25.3 \pm 3.2^{b}$ & $H=39.79 * * *$ \\
\hline • Endemism & $1.0 \pm 0.9^{\mathrm{a}}$ & $0.7 \pm 0.7^{\mathrm{a}}$ & $4.1 \pm 1.4^{\mathrm{b}}$ & $H=38.88 * * *$ \\
\hline - Taxonomic singularity & $0.41 \pm 0.09^{\mathrm{a}}$ & $0.49 \pm 0.11^{b}$ & $0.46 \pm 0.04^{b}$ & $H=10.67 * *$ \\
\hline \multicolumn{5}{|l|}{ Soil seed bank } \\
\hline - Species richness & $9.4 \pm 2.3^{\mathrm{a}}$ & $9.1 \pm 2.9^{\mathrm{a}}$ & $19.1 \pm 5.4^{\mathrm{b}}$ & $F=22.62 * * *$ \\
\hline - Endemism & $0.7 \pm 0.67^{\mathrm{a}}$ & $1 \pm 0.67^{\mathrm{a}}$ & $2.7 \pm 1.16^{\mathrm{b}}$ & $H=15.9$ *** \\
\hline - Taxonomic singularity & $0.31 \pm 0.07^{\mathrm{a}}$ & $0.36 \pm 0.06^{\mathrm{a}}$ & $0.45 \pm 0.06^{\mathrm{b}}$ & $F=11.58^{* * *}$ \\
\hline
\end{tabular}

\section{Biodiversity of the herbaceous layer}

The analysis of biodiversity components carried out with the 60 quadrats of the herbaceous layer had significant differences (indicated by the Kruskal-Wallis tests) between the three vegetation patches for species richness, endemic taxa and taxonomic singularity (Table 3 ). As expected, the herbaceous species density was higher

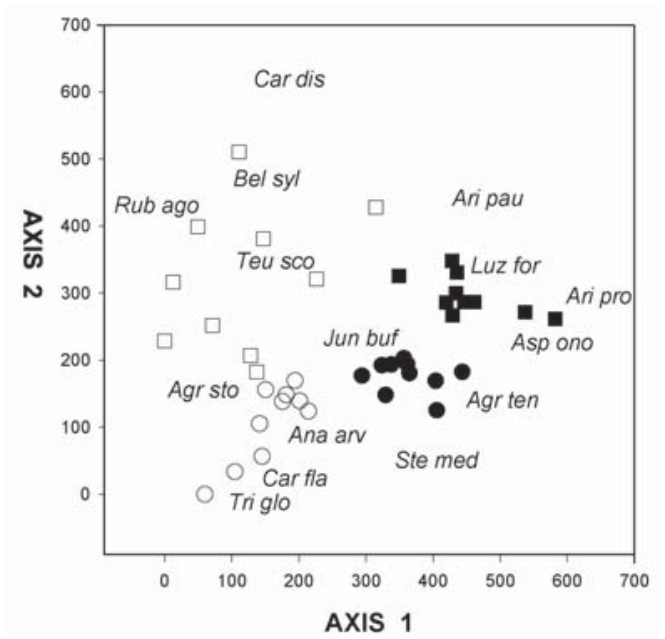

Fig. 2. DCA ordination of seed bank samples from the Quercus suber forest $(\bigcirc)$ and the $Q$. canariensis forest $(-)$; and of adjacent quadrat inventories from the $Q$. suber forest $(\square)$ and from the $Q$. canariensis forest $(\square)$. Abbreviations: Agr sto = Agrostis stolonifera; Agr ten = Agrostis tenerrima; Ana arv = Anagallis arvensis; Ari pau = Aristolochia paucinervis; Ari pro = Arisarum proboscideum; Asp ono=Asplenium onopteris; Bel syl = Bellis sylvestris $;$ Car dis = Carex distachya $;$ Car fla $=$ Carex flacca; Jun buf = Juncus bufonius; Luz for = Luzula forsteri; Rub ago = Rubia agostinhoi; Ste med = Stellaria media $;$ Teu sco = Teucrium scorodonia $;$ and Tri glo = Trifolium glomeratum. in the grassland (mean of 25 taxa.0.25- $\mathrm{m}^{-2}$ ) than in the forest patches ( 6 taxa. $0.25-\mathrm{m}^{-2}$; see Table 3 ). Accordingly, the density of endemic herbaceous taxa was also higher in the grassland (mean of 4 taxa.0.25- $\mathrm{m}^{-2}$ ) than in forests (1 taxon.0.25- $\mathrm{m}^{-2}$ ). The concentration of taxonomically singular herbaceous species was similar between the $Q$.canariensis forest understorey (mean of 0.49) and the grassland (0.46), and higher than in the $Q$. suber forest $(0.41)$.

The biodiversity components had similar patterns for the soil seed bank samples (Table 3). Richness of species and endemic taxa in the seed bank were both lower for the forest soil samples than for the adjacent grassland soil. However, unlike in the vegetation, mean taxonomy singularity for the soil seed bank was higher in the grassland than in the two forest patches.

Table 4. Number of species belonging to different life forms, recorded in the forest and grassland patches (0.1-ha scale). The local species pool of the forest-grassland mosaic has been estimated. Site diversity is the cumulative richness of the (epigeal) vegetation and the soil seed bank.

\begin{tabular}{lcccr}
\hline Life form & $\begin{array}{c}\text { Quercus } \\
\text { suber } \\
\text { forest }\end{array}$ & $\begin{array}{c}\text { Quercus } \\
\text { canariensis } \\
\text { forest }\end{array}$ & Grassland & $\begin{array}{c}\text { Local } \\
\text { pool }\end{array}$ \\
\hline Trees and tall shrubs & 8 & 8 & 0 & 8 \\
Shrubs & 11 & 4 & 0 & 14 \\
Lianas & 2 & 3 & 0 & 3 \\
Perennial herbs & 33 & 37 & 28 & 78 \\
Annuals & 12 & 4 & 65 & 78 \\
Vegetation diversity & 66 & 56 & 93 & 181 \\
Site diversity & 78 & 71 & 113 & 212 \\
\hline
\end{tabular}




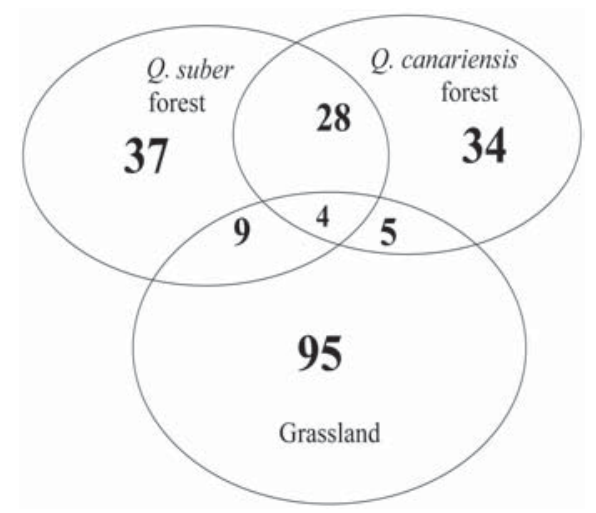

Fig. 3. Local species pool of the forest/grassland mosaic. The total of 212 plant species inventoried is graphically distributed among the three vegetation patches studied.

\section{Floristic diversity at 0.1-ha scale}

Forest communities had relatively high (epigeal) plant species richness (56-66 species.0.1-ha ${ }^{-1}$ ) and a variety of life forms (Table 4). Perennial herbs and shrubs were the dominant life forms. Adding the floristic diversity buried in the soil (as seed bank), the 'site diversity' increased by $18 \%$ in the $Q$. suber patch (78 species) and $27 \%$ in the $Q$. canariensis patch (71 species).

Species richness of the open grassland community (93 species; 113 species including seed bank) was higher than that of forests, but was restricted to herbaceous life forms (Table 4). Therophytes (annuals) dominated the grassland patch $(70 \%$ of species) but were less important in forests, especially in the semi-deciduous $Q$. canariensis patch (7\% of species).

\section{Diversity of the landscape mosaic}

The number of plant species inventoried in the three vegetation patches examined was 212 (including those found only in the soil seed bank). Only four species were common to the three sites and 28 other species were common to the two forest patches. The grassland patch had only 13 species in common with the $Q$. suber forest and nine species with the $Q$. canariensis forest (see Fig. 3).

\section{Discussion}

\section{Soil seed bank in Mediterranean forests}

The seed bank is a biased history of the plant community (Baker 1989). In the shaded forest soil, seeds of light demanding species may remain viable, long after the mother plant has died; in fact, those species probably are no longer present in the (epigeal) vegetation. Plant species present in the soil seed bank but not in the vegetation are indeed part of the forest diversity and can appear after a gap formation by tree fall, local fire, forest clearing or other disturbance.

In the Mediterranean forests studied, the soil seed density was relatively high (11200 - 14100 seed.m ${ }^{-2}$ ) and species rich (27 to 32 species) compared with a set ( $n=14$ ) of ancient temperate forests reviewed by Bossuyt \& Hermy (2001): mean of 3083 seed. $\mathrm{m}^{-2}$ and 20 species. Most of the species in the soil seed bank were herbaceous, but there were some remarkable exceptions of woody species with persistent seed bank, reviewed below.

Recent forests developed on heathlands are known for having high seed densities in the soil seed bank. In the above cited review of European forests (Bossuyt \& Hermy 2001), the mean seed density reported for forest soil on former heathlands was 17890 seed.m $\mathrm{m}^{-2}$ and the mean species richness only 12 .

Calluna vulgaris was one of the main species in the seed bank of this forest type; in the data base compiled by Thompson et al. (1997) this species is remarkable by having a high density (up to $68000 \mathrm{seed} . \mathrm{m}^{-2}$ ) and high seed longevity (more than $68 \mathrm{yr}$ ). The Mediterranean Erica scoparia and E. arborea were the main species in the soil seed bank of the forest studied, but they were also present in the forest understorey: e.g. E. arborea represented 13 to $33 \%$ of the shrub cover (App. 1). They are typical components of the forest understorey in the Aljibe Mountains (Ojeda et al. 2000).

In closed, old forests, adult heath plants senesce but seeds can persist in the soil. We are unaware of studies on the longevity of their seeds, but such seeds are found in forests not disturbed over the last $50 \mathrm{yr}$. In the Canarian laurel-forest, E. arborea is dominant in the soil seed bank ( $71 \%$ of the seeds), and behaves as a pioneer species: it does not germinate in shaded conditions unless a forest gap is opened (Fernández-Palacios \& Arévalo 1998). Arbutus unedo is another species in the same family (Ericaceae), but with a contrasting regeneration pattern: it was absent from the seed bank and is rarely found as seedlings (Marañón et al. unpubl.), despite being well represented in the forest overstorey cover (e.g. $14 \%$ in the Q. canariensis forest).

Species in the Cistaceae are frequent and abundant 
in the seed bank of Mediterranean forests and shrublands (Thanos et al. 1992). Up to 7000 seed. $\mathrm{m}^{-2}$ of Cistus ladanifer were found in the soil of a pine forest, $12 \mathrm{yr}$ after it was burned (Trabaud et al. 1997). In the present study, we found 120-220 seed.m ${ }^{-2}$ of C. salvifolius in the forest soil. In general, Cistus spp. are light demanding, they can colonise woodlands after disturbances and then persist for a long time in the soil seed bank.

Rubus ulmifolius seeds were found, although at low densities $\left(20\right.$ seed. $\left.\mathrm{m}^{-2}\right)$, in the more moist $Q$. canariensi forest soil. Seeds of Rubus spp. were also relatively frequent (found in 15 of 20 studies) in the European temperate forests reviewed by Bossuyt \& Hermy (2001). They can accumulate a relatively dense reserve of seeds in the soil (up to 2718 seed. $\mathrm{m}^{-2}$ ) and persist a long time (more than $80 \mathrm{yr}$ ), according to the maximum values compiled in the European seed bank data base (Thompson et al. 1997).

There were no seedlings of woody Fabaceae in the forest soil samples, despite the abundance of endemic gorses Genista triacanthos and Ulex borgiae (31 and $39 \%$ cover respectively) in the cork oak forest. Woody legumes are frequent in Mediterranean shrublands; they have hard seeds and persistent soil seed banks, although with low density (e.g. Aparicio \& Guisande 1997; Marañón 2001). On the other hand, the production of seeds is relatively low, which could explain their absence from the soil samples. In a program to collect seeds of endemic legumes from the study area, $G$. triacanthos yielded a high proportion of empty pods, and $U$. borgiae a high rate of seed damage by insect larvae (Arroyo pers. obs.). Moreover, the large and sparsely distributed legume seeds would be less likely to be sampled by the soil cores than the many small heather seeds.

\section{Seed bank and community biodiversity}

Mediterranean forests and shrublands are richer in species than comparable communities in temperate Europe (Naveh \& Whittaker 1979; Grubb 1987). The studied forest communities (dominated by $Q$. suber and $Q$. canariensis) have relatively high (epigeal) diversity (66 and 56 species.0.1-ha ${ }^{-1}$ respectively) within the context of Mediterranean vegetation (Westman 1988; Ojeda et al. 2000; Table 5). The grassland patch, with 93 species.0.1-ha ${ }^{-1}$, was even more species rich, although limited to the herbaceous life-form (that is, with lower life form richness).

The forested environment has a remarkable vertical heterogeneity, with tree, liana, shrub and herbaceous layers. Management of the cork oak $(Q$. suber) forest generates local disturbances every nine years, caused by the extraction of cork and shrub clearing around oak trunks: these local disturbances increase spatial heterogeneity. The soil seed bank is a reflection of the microsite heterogeneity and the forest dynamics. There were 31 species found exclusively in the soil seed bank (and not in the vegetation), including forest species such as Calamintha nepeta (Lamiaceae). However, most of the hidden biodiversity was composed of well known species of exposed and illuminated sites, such as Juncus bufonius (1333 seed. $\mathrm{m}^{-2}$ ), Trifolium campestre (537 seed. $\mathrm{m}^{-2}$ ), Anagallis arvensis (477 seed. $\mathrm{m}^{-2}$ ) and Stellaria media (458 seed. $\mathrm{m}^{-2}$ ), having the ability to form persistent seed banks. They might be the reflection of past disturbances opening gaps in the forest. Alternatively, they could have been brought into the forest soil by large herbivores, such as red deer, from grassland patches nearby. Small seeded herbs are frequently dispersed by endozoochory in the Mediterranean landscapes (Malo \& Suárez 1995).

Mediterranean grasslands are species-rich communities with a high proportion of annual species. The role of seed banks is crucial in maintaining the co-existence of such a high density of different species in a temporally variable environment (e.g. Shmida \& Ellner 1984; Espigares \& Peco 1995; Marañón 1998). The 20 species found in the seed bank but not in the grassland vegetation represented $18 \%$ of the site diversity; that is, at least one sixth of the grassland biodiversity was hidden in the ground and not visible. Some of the species abundant in the seed bank, but that were not present in the vegetation are typical of wet microsites, such as Juncus bufonius (2626 seed. $\mathrm{m}^{-2}$ ), Centaurium maritimum (696 seed. $\mathrm{m}^{-2}$ ) and Lythrum acutangulum (477 seed.m ${ }^{-2}$ ); they are probably a reflection of past wet periods (see Marañón 1998).

The patterns for biodiversity components in the herbaceous layer, in the three patches, were similar for the (epigeal) vegetation and for the soil seed bank (Table 3 ). The exception was the higher taxonomic singularity of the herbaceous understorey in the $Q$. canariensis for-

Table 5. Comparative values of species richness at the 0.1-ha scale, for different mediterranean-type vegetation types.

\begin{tabular}{llrl}
\hline Community type & Location & $\begin{array}{c}\text { Mean species } \\
\text { richness }\end{array}$ \\
\hline Forest and shrubland $(n=9)$ & France & 33 & Westman (1987) \\
Woodland and shrubland $(n=14)$ & California & 36 & Westman (1987) \\
Mallee shrubland $(n=97)$ & Australia & 47 & Westman (1987) \\
Quercus canariensis forest $(n=1)$ & Spain & 56 & This study \\
Fynbos shrubland $(n=45)$ & South Africa & 64 & Westman (1987) \\
Quercus suber forest $(n=1)$ & Spain & 64 & This study \\
Forest and shrubland $(n=4)$ & Spain & 71 & Ojedaetal. (2000) \\
Woodland and shrubland $(n=10)$ & Israel & 88 & Westman (1987) \\
Grassland $(n=1)$ & Spain & 93 & This study \\
Oak savanna grassland $(n=1)$ & Spain & 135 & Marañón (1985) \\
\hline
\end{tabular}


ests; this pattern not being paralleled in the soil seed bank. Previous studies at regional level documented the highest taxonomic singularity of the woody species in the $Q$. canariensis understorey (Ojeda et al. 2000). Species belonging to low diversified genera (within the western Andalusian context) such as Hedera, Ruscus, Rubus and Rhododendron were responsible for these higher values.

\section{Biodiversity of the mosaic landscape}

The mountain landscape in Los Alcornocales Natural Park (S. Spain) is a mosaic of forests, shrublands and grasslands. The current vegetation mosaic has been produced by interplay of a heterogeneous physical environment, with spatial changes in rock and soil types, in light conditions and in nutrient and water availability, combined with the impact of human activities, both past and present.

The two forest patches had a relatively high overlap in species composition (27\%), probably the reflection of a bi-directional dispersal flow of diaspores and successful recruitment between the two similar habitats. In fact, $Q$. suber and $Q$. canariensis frequently form mixed forests in the study area. In contrast, the ecological filter between the forest and grassland patches must be 'finer' and thus fewer species share the two habitats. The grassland patch shared $8 \%$ species with the $Q$. suber patch and $5 \%$ with the $Q$. canariensis patch. $Q$. suber forests are more frequently disturbed, due to cork harvesting and management, and would offer more patches suitable for colonisation by grassland species.

The actual pool of each forest patch is determined by the set of available species in the surrounding landscape capable of coexisting in that community, and the environmental sieve filtering species by abiotic factors and biotic interactions (Zobel 1997). For example, shade conditions in forest patches may inhibit seedling establishment of light demanding species dispersed from the open grassland. On the other hand, competitive interactions in the open, light exposed patch, may eliminate some shade tolerant herbaceous species dispersed from the forest understorey (see results of reciprocal transplants between forest and grassland habitats in Marañón \& Bartolome 1993).

Seed banks have been used to recover plants of threatened endemic species, such as the woody legume Echinospartum algibicum (Aparicio \& Guisande 1997). At the community level, soil seed banks containing seeds of ancient woodland species have been used to mitigate new development areas, by translocating seed rich topsoil from forest sites (Dougall \& Dodd 1997). The conservation of Mediterranean forest communities should take into account the regeneration biology, in- cluding seed banks, of all their species components, with particular focus on endemic taxa.

\section{Soil seed bank and forest conservation}

The results presented here have implications for forest conservation. The role of soil seed banks for the preservation of species richness in the community is known. We have now shown that these seed reservoirs are also important for the conservation of other biodiversity components, such as endemism and taxonomic singularity. There is no reason to expect that the representation of endemism and taxonomic singularity in the soil seed banks should be different from that in the epigeal vegetation. However, it is important to know that these components are also relatively well preserved in the soil and may recover after disturbances.

Acknowledgements. We thank Rosario Hidalgo and Eduardo Jiménez for helping with the field work, José M. Higuera and Jesús V. García for facilities at the University of Seville greenhouse, and two anonymous reviewers for improving the manuscript. The study has been supported by a contract of the 'Consejería de Medio Ambiente' of the Regional Andalusian Government, by the CICYT-FEDER project 1FD97-0743C03-03, and by DGES grant PB95-551.

\section{References}

Anon. 1990. Mapas de usos del suelo. In: Avance de planificación del Parque Natural Los Alcornocales. Junta de Andalucía, Sevilla, ES.

Anon. 1997a. P.O.R.N. y P.R.U.G. del Parque Natural Los Alcornocales. Consejería de Medio Ambiente, Junta de Andalucía, Sevilla, ES.

Anon. 1997b. STATISTICA for Windows, v. 5.1. StatSoft, Tulsa, OK, US.

Aparicio, A. \& Guisande, R. 1997. Replenishment of the endangered Echinospartum algibicum (Genisteae, Fabaceae) from the soil seed bank. Biol. Conserv. 81:267-273.

Aparicio, A., Albadalejo, R.G. \& Ceballos, G.L. 2002. Genetic differentiation in silicicolous Echinospartum (Leguminosae) indicated by allozyme variability. Plant Syst. Evol. 230: 189-201.

Baker, H.G. 1989. Some aspects of the natural history of seed banks. In: Leck, M.A., Parker, V.T. \& Simpson, R.L. (eds.) Ecology of soil seed banks, pp. 9-21. Academic Press, San Diego, CA, US.

Bossuyt, B. \& Hermy, M. 2001. Influence of land use history on seed banks in European temperate forest ecosystems: a review. Ecography 24: 225-238.

Calvo, L., Herrero, B. \& Bravo, F. 1999. The influence of fire on the seed bank in the soil of a Quercus faginea forest (NW Spain). Ann. For. Sci. 56: 249-258.

Dougall, T.A.G. \& Dodd, J.C. 1997. A study of species 
richness and diversity in seed banks and its use for the environmental mitigation of a proposed holiday village development in a coniferized woodland in south east England. Biodivers. Conserv. 6: 1413-1428.

Espigares, T. \& Peco, B. 1995. Mediterranean annual pasture dynamics: impact of autumn drought. J. Ecol. 83: 135142.

Fernández-Palacios, J.M. \& Arévalo, J.R. 1998. Regeneration strategies of tree species in the laurel forest of Tenerife (The Canary Islands). Plant Ecol. 137: 21-29.

Ferrandis, P., Herranz, J.M. \& Martínez-Sánchez, J.J. 1996. The role of soil seed bank in the early stages of plant recovery after fire in a Pinus pinaster forest in SE Spain. Int. J. Wildl. Fire 6: 31-35.

Ferrandis, P., Herranz, J.M. \& Martínez-Sánchez, J.M. 1999. Fire impact on a maquis soil seed bank in Cabañeros National Park (Central Spain). Isr. J. Plant Sci.47: 17-26.

Grubb, P.J. 1987. Global trends in species-richness in terrestrial vegetation: a view from the northern Hemisphere. In: Gee, J.H.R. \& Giller, P.S. (eds.) Organization of communities. Past and present, pp. 99-118. Blackwell, Oxford, UK.

Hyatt, L.A. \& Casper, B.B. 2000. Seed bank formation during early secondary succession in a temperate deciduous forest. J. Ecol. 88: 516-527.

Levin, D.A. 1990. The seed bank as a source of genetic novelty in plants. Am. Nat. 135 : 563-572.

Major, J. \& Pyott, W.T. 1966. Buried, viable seeds in two California bunchgrass sites and their bearing on the definition of a flora. Vegetatio 13: 253-282.

Malo, J.E. \& Suárez, F. 1995. Herbivorous mammals as seed dispersers in a Mediterranean dehesa. Oecologia 104: 246-255.

Marañón, T. 1985. Diversidad florística y heterogeneidad ambiental en una dehesa de Sierra Morena. An. Edafol. Agrobiol. 44: 1183-1197.

Marañón, T. 1998. Soil seed bank and community dynamics in an annual-dominated Mediterranean salt-marsh. J. Veg. Sci. 9: 371-378.

Marañón, T. 2001. Ecología del banco de semillas y dinámica de comunidades mediterráneas. In: Zamora, R. \& Pugnaire, F. I. (eds.) Ecosistemas mediterráneos. Análisis funcional, pp. 153-181. CSIC-AEET, Madrid, ES.

Marañón, T. \& Bartolome, J. W. 1993. Reciprocal transplants of herbaceous communities between Quercus agrifolia woodland and adjacent grassland. J. Ecol. 81: 673-683.

McCune, B. \& Mefford, M.J. 1999. PC-ORD. Multivariate analysis of ecological data, version 4. MjM Software Design, Gleneden Beach, OR, US.

Mueller-Dombois, D. \& Ellenberg, H. 1974. Aims and methods of vegetation ecology. Wiley, New York, NY, US.

Naveh, Z. \& Whittaker, R.H. 1979. Structural and floristic diversity of shrublands and woodlands in northern Israel and other Mediterranean areas. Vegetatio 41: 171-190.

Ojeda, F., Arroyo, J. \& Marañón, T. 1995. Biodiversity components and conservation of Mediterranean heathlands in Southern Spain. Biol. Conserv. 72: 61-72.

Ojeda, F., Marañón, T. \& Arroyo, J. 2000. Plant diversity patterns in the Aljibe Mountains (S. Spain): a comprehen- sive account. Biodivers. Conserv. 9: 1323-1343.

Pake, C.E. \& Venable, D.L. 1995. Is coexistence of Sonoran Desert annuals mediated by temporal variability in reproductive success? Ecology 76: 246-261.

Shmida, A. \& Ellner, S. 1984. Coexistence of plant species with similar niches. Vegetatio 58: 29-55.

Spies, T. A. \& Turner, M. G. 1999. Dynamic forests mosaics. In: Hunter, M. L. (ed.) Maintaining biodiversity in forest ecosystems, pp.95-160. Cambridge University Press, Cambridge, UK.

Thanos, C.A., Georghious, K., Kadis, C. \& Pantazi, C. 1992. Cistaceae: A plant family with hard seeds. Isr.J. Bot. 41: 251-263.

Thompson, K., Bakker, J.P. \& Bekker, R.M. 1997. The soil seed banks of North West Europe. Cambridge University Press, Cambridge, UK.

Trabaud, L. 2000. Seeds: their soil bank and their role in postfire recovery of ecosystems of the Mediterranean basin. In: Trabaud, L. (ed.) Life and environment in the Mediterranean, pp. 229-259. WIT Press, Southampton, UK.

Trabaud, L., Martínez-Sánchez, J.J., Ferrandis, P., GonzálezOchoa, A.I. \& Herranz, J.M. 1997. Végétation épigée et banque de semences du sol: leur contribution à la stabilité cyclique des pinèdes mixtes de Pinus halepensis et $P$. pinaster. Can. J. Bot. 75: 1012-1021.

Valbuena, L. \& Trabaud, L. 1995. Comparison between the soil seed banks of a burnt and an unburnt Quercus pyrenaica Willd. forest. Vegetatio 119: 81-90.

Valdés, B., Talavera, S. \& Fernández-Galiano, E. 1987. Flora vascular de Andalucía Occidental, Vols. 1-3. Ketres, Barcelona, ES.

Venable, D.L. \& Brown, J.S. 1988. The selective interactions of dispersal, dormancy, and seed size as adaptations for reducing risk in variable environments. Amer. Nat. 131: 360-384.

Westman, W.E. 1988. Vegetation, nutrition and climate data-tables. 3. Species richness. In: Specht, R.L. (ed.) Mediterranean-type ecosystems. A data source book, pp. 81-91. Kluwer, Dordrecht, NL.

Zobel, M. 1997. The relative role of species pools in determining plant species richness: an alternative explanation of species coexistence. Trends Ecol. Evol. 12: 266-269.

Received 16 July 2002; Revision received 6 January 2003 ; Final version received 24 March 2003; Accepted 19 March 2003. Co-ordinating Editor: R. H. Marrs.

For App. 1 \& 2, see JVS/AVS Electronic Archives; www.opuluspress.se/pub/archives/index.htm 